\title{
ANALISIS BANJIR TAHUNAN KOTA SURAKARTA MENGGUNAKAN WATERSHED MODELLING SYSTEM (WMS)
}

\author{
Bagas Hendi Pratama1), RR Rintis Hadiani2), Setiono ${ }^{3)}$ \\ 1) Mahasiswa Fakultas Teknik, Prodi Teknik Sipil, Universitas Sebelas Maret \\ 2) Pengajar Fakultas Teknik, Prodi Teknik Sipil, Universitas Sebelas Maret \\ 3) Pengajar Fakultas Teknik, Prodi Teknik Sipil, Universitas Sebelas Maret \\ Jl. Ir. Sutami 36A, Surakarta 57126; Telp. 0271-634524. Email: \\ Email: mc.bagashendip@gmail.com
}

\begin{abstract}
Surakarta is passed through by several rivers. As a result, the city of Surakarta often encounter floods in case of high rainfall. To know the flood discharge, it is necessary to do hydrological analysis on the watershed. To determine the extent and depth of the flood that occurs, it is necessary to do bydraulic analysis on the river or channel. The purpose of this research is to know the value of Curve Number (CN) of Surakarta River Basin, Peak. flow discharge, Potential area of flood, and potential depth of flood. In this study, the watershed was analyzed using $W$ atershed Modeling System (WMS) and flow simulation was analyzed using HEC-RAS. The calculated flow discharge is a return period of 5, 10, 25, and 50 years. The flow discharge was calculated using SCS method. The analyzed rivers are Brojo, Gajah Putih, Grenjeng, Krembyongan, Pepe Hulu, Pepe Hilir, Premulung and Wingko. Based on the research, Curve Number of Surakarta River Basin is 67,86. The peak discharge in the largest basin, the Pepe Hulu basin, was obtained Q5 $=74,468 \mathrm{~m}^{3} / \mathrm{s}, Q^{10}=91,475 \mathrm{~m}^{3} / \mathrm{s} Q^{25}=110,393 \mathrm{~m}^{3} / \mathrm{s}$, and Q50 $=122,816 \mathrm{~m}^{3} / \mathrm{s}$. Potential total area of 5-year return period $=539871 \mathrm{~m}^{2}$, 10-year return period $=82535 \mathrm{~m}^{2}$, 25-year return period $=1032881 \mathrm{~m}^{2}$, and $50=$ $1091835 \mathrm{~m}^{2}$. Potential Flood 5 yearly floods $=5.09 \mathrm{~m}, 10$ annual $=5.57 \mathrm{~m}, 25$ annual $=8.02 \mathrm{~m}$, and 50 annual $=8.23 \mathrm{~m}$. Kelurahan Banyuanyar has the potential to encounter the largest flood area and the highest flood depth.
\end{abstract}

\begin{abstract}
Abstrak
Kota Surakarta dilewati oleh beberapa sungai. Akibatnya di Kota Surakarta sering terjadi banjir di apabila terjadi curah hujan yang tinggi. Untuk mengetahui debit banjir yang terjadi perlu dilakukan analisis secara hidrologi pada DAS. Untuk mengetahui luasan dan kedalman banjir yang terjadi perlu dilakukan analisis hidrolika pada sungai atau saluran. Tujuan Penelitian adalah untuk mengetahui nilai Curve Number (CN) DAS Kota Surakarta, puncak debit aliran, potensi luasan, dan potensi kedalaman banjir. Pada penelitian Analisis pada DAS digunakan Watershed Modelling System (WMS) dan simulasi aliran menggunakan HECRAS. Debit yang dihitung merupakan debit aliran periode ulang 5, 10, 25, dan 50 tahun. Metode perhitugan debit aliran menggunakan metode SCS. Sungai yang dianalisis adalah Brojo, Gajah Putih, Grenjeng, Krembyongan, Pepe Hulu, Pepe Hilir, Premulung dan Wingko. Berdasarkan penelitian didapatakan CN DAS Kota Surakarta adalah 67,86. Debit puncak pada DAS paling besar, yaitu DAS Pepe Hulu didapatkan $\mathrm{Q}_{5}=74,468 \mathrm{~m}^{3} / \mathrm{s}, \mathrm{Q}_{10}=91,475 \mathrm{~m}^{3} / \mathrm{s} \mathrm{Q}_{25}=110,393 \mathrm{~m}^{3} / \mathrm{s}, \mathrm{dan} \mathrm{Q}_{50}=122,816$ $\mathrm{m}^{3} / \mathrm{s}$. Potensi luasan total banjir periode ulang 5 tahun $=539871 \mathrm{~m}^{2}, 10$ tahun $=82535 \mathrm{~m}^{2}, 25$ tahun $=1032881 \mathrm{~m}^{2}$, dan 50 tahun $=1091835 \mathrm{~m}^{2}$. Potensi Kedalaman banjir periode ulang 5 tahun $=5,09 \mathrm{~m}, 10$ tahun $=5,57 \mathrm{~m}, 25$ tahun $=8,02 \mathrm{~m}$, dan 50 tahun $=8,23 \mathrm{~m}$. Kelurahan Banyuanyar berpotensi mengalami luasan banjir paling besar dan kedalaman banjir paling tinggi.
\end{abstract}

Kata kunci: Watershed Modelling System, SCS, Potensi Banjir Tahunan, Pemetaan Banjir.

\section{PENDAHULUAN}

Adanya banyak sungai yang melewati Kota Surakarta dapat menyebabkan banjir di beberapa titik apabila terjadi hujan yang cukup lama dengan debit yang tidak dapat diperkirakan. Hal ini dapat disebabkan karena saluran yang melewati daerah pemukiman tidak mampu menampung debit yang dihasilkan oleh hujan. Karena adanya siklus hidrologi, aliran permukaan akan menjadi debit pada saluran. Parameter yang mempengaruhi proses hidrologi salah satunya adalah karakter dari DAS. Karakter DAS seperti tanah, pemangaatan lahan, kondisi hidrologi tanah dan tingkat kelengasan dapat dinyatakan dalam suatu indeks yaitu Curve Number $(\mathrm{CN})$. CN merupakan parameter perhitungan hujan-aliran menggunakan metode SCS. Banjir tahunan pada DAS Bengawan Solo Hulu Sub DAS Bengawan Solo Hulu 3 berpotensi banjir Q 5 hingga $Q_{10}$ (Ayu, 2012). Untuk DAS dengan luas lebih dari $500 \mathrm{~km}^{2}$ debit rencana yang digunakan untuk saluran drianase daerah perkotaan digunakan $\mathrm{Q}_{10}$ sampai dengan $\mathrm{Q}_{25}$ (Suripin, 2004). Untuk kejadian ekstrim perlu diketahui banjir akibat debti $Q_{50}$. Pemetaan diperlukan untuk mengetahui lokasi potensi luasan dan kedalaman banjir. Karena banyaknya parameter yang mempengaruhi debit aliran, maka diperlukan model untuk menyederhanakannya. Pemodelan secara digital lebih mudah dan cepat untuk digunakan. Perangkat lunak Watershed Modelling System (WMS) dapat melakukan perhitungan parameter hidrologi dan hasil perhitungannya dapat divisualisasikan.

\section{TINJAUAN PUSTAKA}


Banjir adalah suatu kondisi dimana tidak tertampungnya air dalam saluran pembuang (palung sungai) atau terhambatnya aliran air dalam saluran pebuang, sehingga meluap menggenangi daerah (dataran banjir) sekitarnya (Suripin, 2004).

DAS atau yang biasa disebut dengan Daerah Pengaliran Sungai adalah suatu kesatuan wilayah tata air yang terbentuk secara alamiah. Dimana air meresap atau mengalir melalui sungai dan anak-anak sungai yang bersangkutan. DAS disebut juga sebagai watershed atau catchment area. DAS ada yang kecil dan ada juga yang sangat luas. DAS yang sangat luas bisa terdiri dari beberapa sub DAS dan Sub DAS dapat terrdiri dari beberapa sub DAS - sub DAS tergantung banyaknya anak sungai dari cabang sungai yang ada, yang merupakan bagian dari suatu system sungai utama (Asdak, 1995).

Hujan menjadi sumber dari semua aliran pada sungai maupun di bawah permukaan tanah. Debit yang terjadi pada sungai tergantung pada jumlah intensitas dan distribusi hujan. Apabila data aliran tidak ada, data hujan dapat di alihragamkan untuk memperkirakan debit aliran yang terjadi (Bambang, 2006).

Air hujan sebelum menjadi debit pada aliran sungai akan melalui daerah tangkapan atau DAS. Oleh karena itu, karakteristik DAS berpengaruh terhadap debit aliran. Karakter tanah, pemanfaatan lahan, kondisi hidrologi tanah dan tingkat kelengasan merupakan beberapa karaktere DAS yang memberikan pengaruh penting dalam menentukan hidrograf hujan-aliran pada DAS. Kondisi kondisi yang mempengaruhi tersebut dinyatakan dalam indeks yaitu Curve Number (CN) (Rifai 2015). Jumlah debit limpasan permukaan yang dihasilkan oleh kedalaman curah hujan yang sama pada suatu DAS akan berbeda pada DAS yang lainnya karena pengaruh dari tutupan lahan pada DAS tersebut (Rintis, 2015).

Tinggi permukaan air banjir yang terjadi dapat diketahui apabila diketahui bentuk permukaan DAS. Bentuk permukaan DAS dapat ditentukan menggunakan elevasi permukaan tanah. Pada umumnya elevasi permukaan tanah digambarkan menggunakan peta kontur atau peta topografi. Model Elevasi Digital (Digital Elevation Model, DEM) merupakan peta digital yang dapat memunculkan informasi berupa morfologi permukaan tanah. Data DEM dapat memvisualisasikan relief bumi dalam bentuk 3D, sehingga dapat diterapkan untuk analisa karakteristik fisik dalam pengelolaan sebua DAS (Sulianto, 2006).

Digital Elevation Model disingkat DEM adalah data digital yang menggambarkan bentuk bagian permukaan bumi yang terdiri dari kumpulan titik titik koordinat hasil sampling dari permukaan dengan algoritma yang didefinisikan permukaan tersebut menggunakan himpunan koordinat (Permen PU 2013).

Dalam perangkat lunak WMS terdapat berbagai lingkungan pemodelan hidrologi yang terintegrasi dengan model yang telah berkembang sebelumnya, termasuk penggambaran atau delinasi DAS, perhitungan geometrik, perhitungan parameter hidrologi (Curve Number, waktu konsentrasi, kedalaman curah hujan dll) dan dapat memvisualisasikan hasil perhitungan. Data grafis dari Sistem Informasi Geografis dapat digabungkan dengan pemodelan dalam WMS membuat model WMS tepat untuk menghitung debit aliran yang dipengaruhi oleh parameter dari karakteristik DAS. (Sharkh, 2009).

Salah Satu model hidrologi yang dapat digunakan pada WMS adalah model hidrologi HEC-HMS. Model HECHMS merupakan salah satu model hidrologi. Model hidrologi ini dapat mengalihragkan hujan menjadi aliran dalam suatu DAS. HEC-HMS memiliki kemampuan untuk mensimulasikan aliran dari hujan dan karakteristik DAS sebagai masukannya. Output pada HEC-HMS dapat berupa hidrograf atau dalam bentuk tabel (Rifai, 2015).

Salah satu model hidrolika yang terhubung dengan WMS adalah model hidrolika dengan HEC-RAS. Perhitungan Hidrolika pada saluran dilakukan menggunakan HEC-RAS. HEC-RAS dirancang untuk melakukan simulasi aliran satu dimensi. HEC-RAS dipilih karena interface berbasis grafis sehingga mudah untuk digunakan (Restu, 2016).

\section{METODE}

Peta yang digunakan adalah Peta DEM SRTM 30m, Peta penggunaan lahan, Peta Jenis Tanah, Peta Hidrologi, Peta Hipsografi, Peta pengukuran Sungai Pepe Hulu dan Peta pengukuran Sungai Premulung. Penyiapan data peta sebagai input pada WMS menggunakan bantuan perangkat lunak ArcMap. 
Penentuan Karakteristik DAS Kota Surakarta menggunakan WMS. Modul perhitungan debit yang digunakan adalah HEC-HMS. Metode perhitungan hujan efektif menggunakan dan metode perhitungan pengalihragaman hujan menjadi debit aliran menggunakan metode SCS.

Data curah hujan yang digunakan adalah data curah hujan stasiun Sukoharjo, Baki, Kalijambe, Mojolaban, Nepen, Ngemplak, dan Pabelan. Perbaikan data hujan menggunakan reciprocal method. Kepanggahan data ditentukan menggunakan kurva massa ganda. Hujan wilayah ditentukan menggunakan Metode Poligon Thiessen. Hujan periode ulang dihitung menggunakan distribusi Log Pearson III. Pengujian distribusi hujan dihitung menggunakan metode Chi Kuadrat. Hujan jam jam an dihitung menggunakan metode Mononobe dan disusun menggunkan Alternate Block Method (ABM) untuk membuat Hyetograf distribusi hujan jam jam an.

Perhitungan luasan dan kedalaman banjir digunakan perangkat lunak HEC-RAS dengan data input debit menggunakan hidrograf aliran permukaan DAS dan geometri sungai menggunakan peta pengukuran sungai dan hasil survey. Simulasi aliran yang digunakan adalah simulasi aliran tidak tetap.

Pemetaan luasan banjir dan kedalaman banjir digunakan bantuan perangkat lunak ArcMap.

\section{HASIL DAN PEMBAHASAN}

\section{Pengolahan Data DEM}

Prosedur penyiapan data peta DEM menggunakan ArcMap sebagai input pada WMS adalah sebagai berikut:

1. Memotong Peta DEM SRTM menggunakan tool Clip

2. Melakukan proyeksi peta DEM SRTM menjadi Universal Transverse Mercator (UTM) WGS 1984 49S menggunakan tool projection.

3. Melakukan rekondisi peta DEM SRTM supaya terbentuk relief sungai. menggunakan tool dem reconditioning

Prosedur penyiapan data peta DEM menggunakan ArcMap sebagai input pada geometri HEC-RAS adalah sebagai berikut:

1. Memproyeksikan peta hipsografi menjadi UTM WGS 1984 49S menggunkan tool Projection

2. Memotong peta hipsografi sesuai dengan wilayah Kota Surakarta menggunakan tool Clip

3. Melakukan interpolasi peta hipsografi dari shapefile menjadi raster menggunakan tool Topo to Raster

4. Menyiapkan peta Pengukuran Sungai Pepe Hulu dan Sungai Premulung dengan cara mengkopi objek objek yang diperlukan ke dalam file baru.

5. Melakukan konversi format data peta dari AutoCAD menjadi geodatabase agar bisa dibaca pada program ArcMap menggunakan tool CAD to Geodatabase.

6. Mengkonversi keterangan titik elevasi cross section dari annotation menjadi point menggunakan tool feature to point.

7. Membuat feature point dengan koordinat koordinat benchmark pengukuran sebagai inputnya.

8. Melakukan konversi objek-objek dari format feature menjadi format shapefile menggunakan tool feature class to shapefile.

9. Membenarkan posisi objek-objek menggunakan tool spatial adjustment

10. Menentukan proyeksi menjadi UTM WGS 1984 49S pada objek-objek menggunakan tool Define Projection.

11. Melakukan interpolasi objek-objek tersebut menjadi DEM menggunakan tool Topo to Raster.

12. Memotong output raster pada langkah ke-10 menggunakan tool Clip sesuai dengan batas pengukuran sungai.

13. Melakukan kalibrasi elevasi pada peta DEM pengukuran Sungai Pepe Hulu dan Sungai Premulung menggunakan tool Minus. Untuk Sungai Pepe Hulu elevasi DEM dikurangi $2.5 \mathrm{~m}$ sedangkan pada Sungai Premulung dikurangi $5 \mathrm{~m}$.

14. Menggabungkan seluruh peta DEM menggunakan tool Mosaic to New Raster.

\section{Menentukan Karakter DAS}

Karakter DAS yang akan ditentukan adalah Luas DAS dan Curve Number untuk perhitungan pengalihragaman hujan menjadi hujan-aliran menggunkana metode SCS. Data yang dibutuhkan adalah Peta DEM, Peta Tutupan Lahan skala 1:25.000, Peta Jenis Tanah yang merupakan hasil digitasi peta Geologi Pulau Jawa skala 1:100.000, dan Tabel nilai Curve Number SCS.

Pembuatan DAS dilakukan dengan langkah sebagai berikut

1. Persiapkan satuan dan proyeksi yang digunakan. Satuan yang digunakan adalah meter dan proyeksi yang digunakan adalah UTM 49S.

2. Memasukkan peta DEM wilayah Surakarta sebagai input terrain data.

3. Pilih "Drainage Module" pada toolbar. Klik menubar DEM kemudian pilih "Compute flow direction/ accumulation". 
4. Pilih "Run TOPAZ” untuk membuat DAS menggunakan perhitungan TOPAZ. Maka akan dihasilan aliran sungai seperti pada gambar 1 .

5. Membuat titik outlet pada sungai yang akan dibuatkan DAS-nya menggunakan fitur Create Outlet Point pada Drainage Module.

6. Setelah ditentukan titik titik outlet gunakan Delineate Basin Wizard pada menubar DEM.

7. Karakter yang didapatkan dari prosedur ini adalah Bentuk DAS dan Luas DAS berdasarkan elevasi peta DEM yang digunakan. Hasil dari prosedur ini dapat dilihat pada Gambar 2.

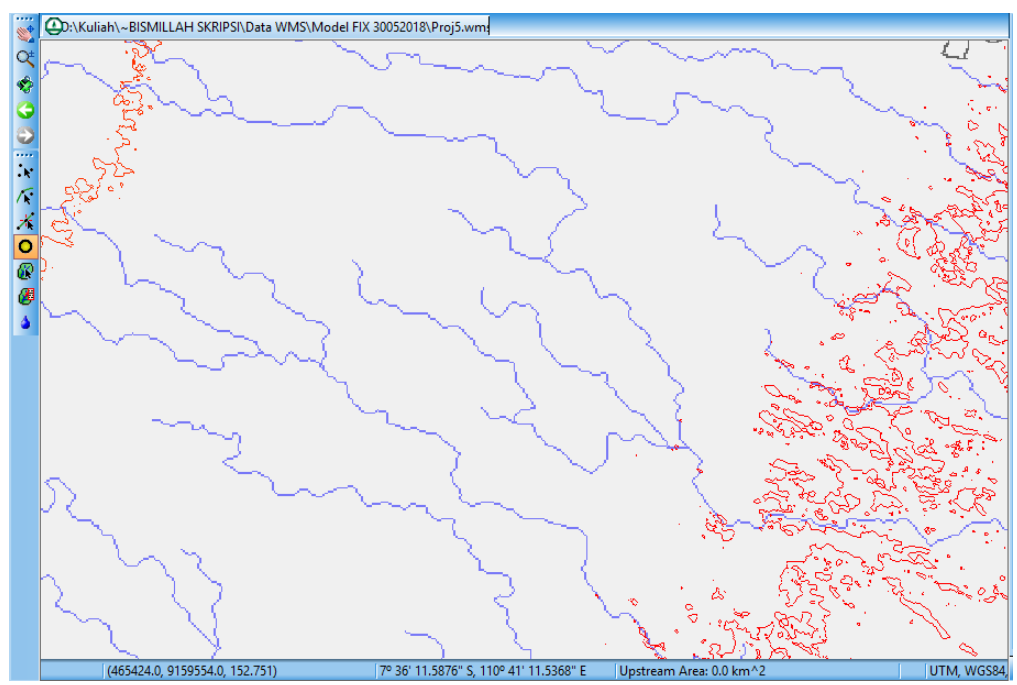

Gambar 1 Hasil Aliran Sungai Menggunakan TOPAZ (Sumber: Hasil Analisis)

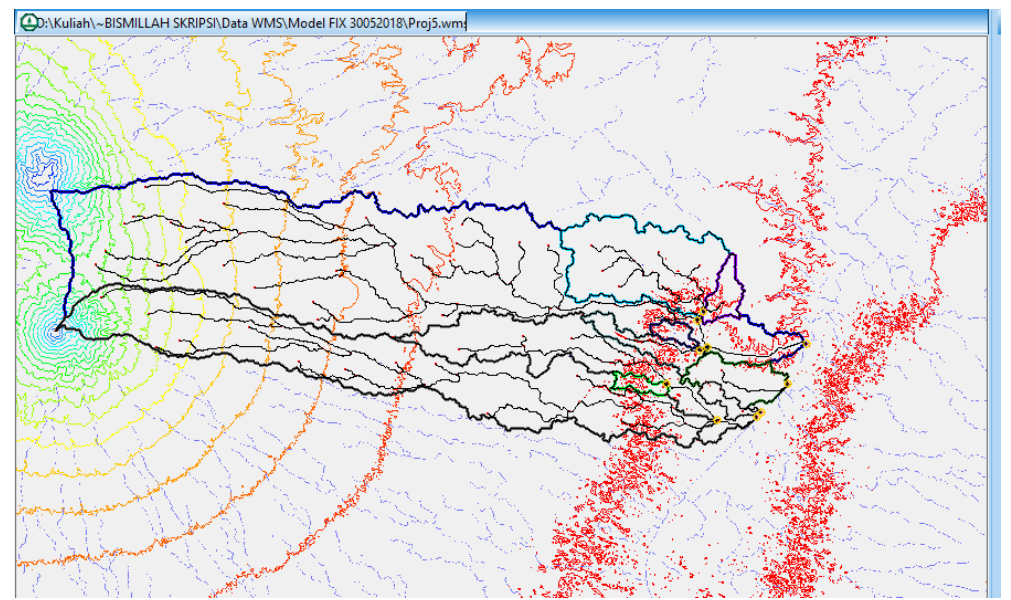

Gambar 2 Hasil Pembuatan DAS (Sumber: Hasil Analisis)

Perhitungan Karakter DAS dilakukan Data yang digunakan adalah tabel nilai CN, peta tutupan lahan, dan peta jenis tanah. Sebelum seluruh input dimasukkan perlu dibuat terlebih dahulu coverage untuk Land Use dan Soil Type. Database nilai CN dibuat menggunakan program notepad dengan input sesuai dengan tabel 6 dan tulisan dibuat dengan format seperti pada Gambar 3. Kemudian data tersebut di simpan dalam format ekstensi ".TBL". 


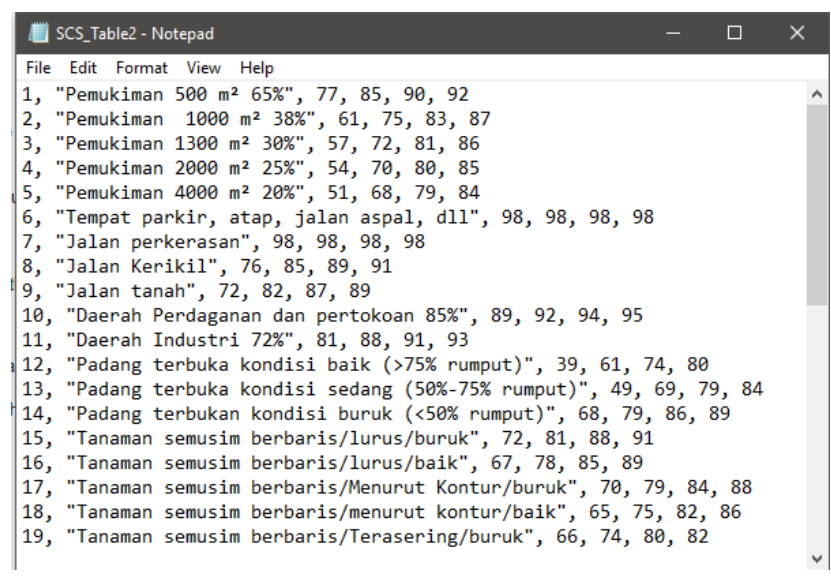

Gambar 3 Format Penulisan Tabel CN Sebagai Input WMS (Sumber: Hasil Analisis)

Sebelum peta tutupan lahan dan peta jenis tanah diinput pada program WMS terlebih dahulu ditambahkan atribut dengan jenis tutupan lahan dan kelompok hidrologi tanah yang sesuai dengan SCS pada ArcMap. Data peta tutupan lahan dan peta jenis tanah diinput ke perangkat lunak WMS pada fitur "GIS data" kemudian dikonversi ke fitur "Coverage". Tampilan peta tutupan lahan dan peta jenis tanah dapat dilihat pada Gambar 4

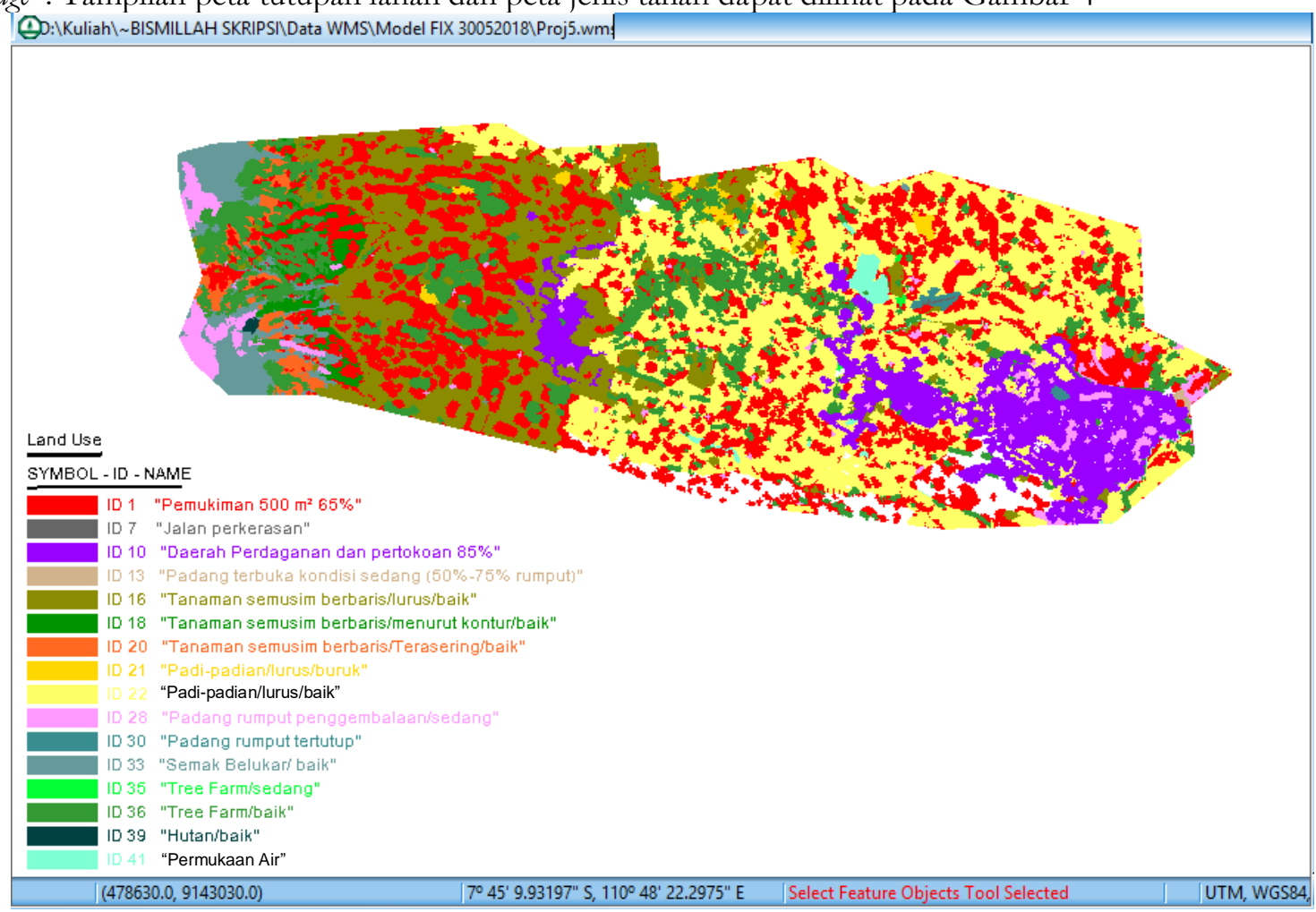

(a) 


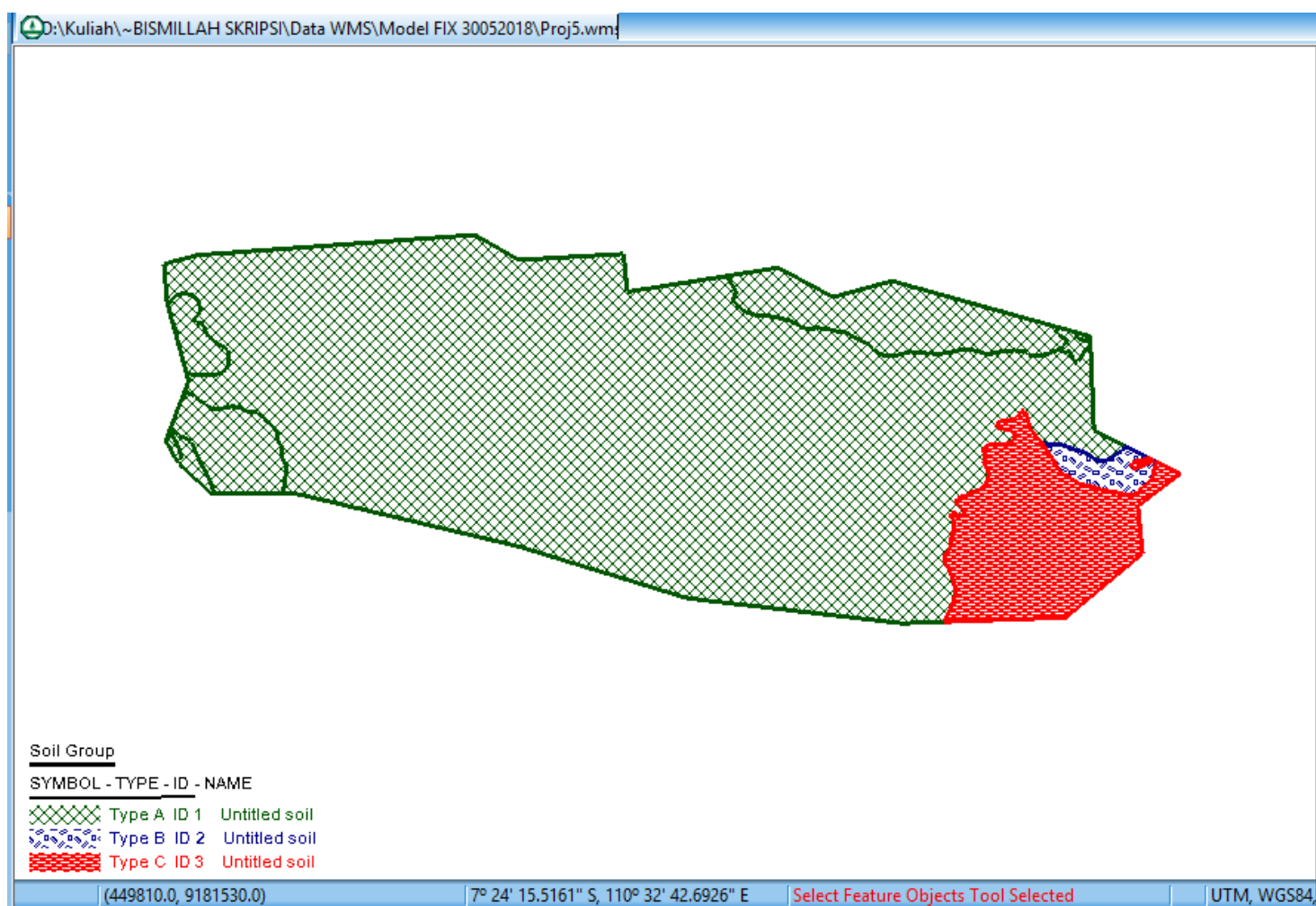

(b)

Gambar 4(a). Tampilan Peta Tutupan Lahan pada WMS; (b) Tampilan Peta Jenis Tanah pada WMS (Sumber: Hasil Analisis)

Nilai Curve Number dihitung dengan langkah seperti berikut:

1. Membuka Hydrologic Module.

2. Memilih "Compute GIS Attribute" pada menu bar Compute.

3. Import data tabel nilai Curve Number yang telah dibuat sebelumnya.

4. Pilih perhitungan "SCS Curve Number".

5. Pilih coverage sesuai dengan data peta. Pilihan yang digunakan dapat dilihat pada Gambar 5 .

6. Klik OK.

Rekapitulasi hasil perhitungan Karakter DAS dapat dilihat pada gambar 5 dan tabel 1

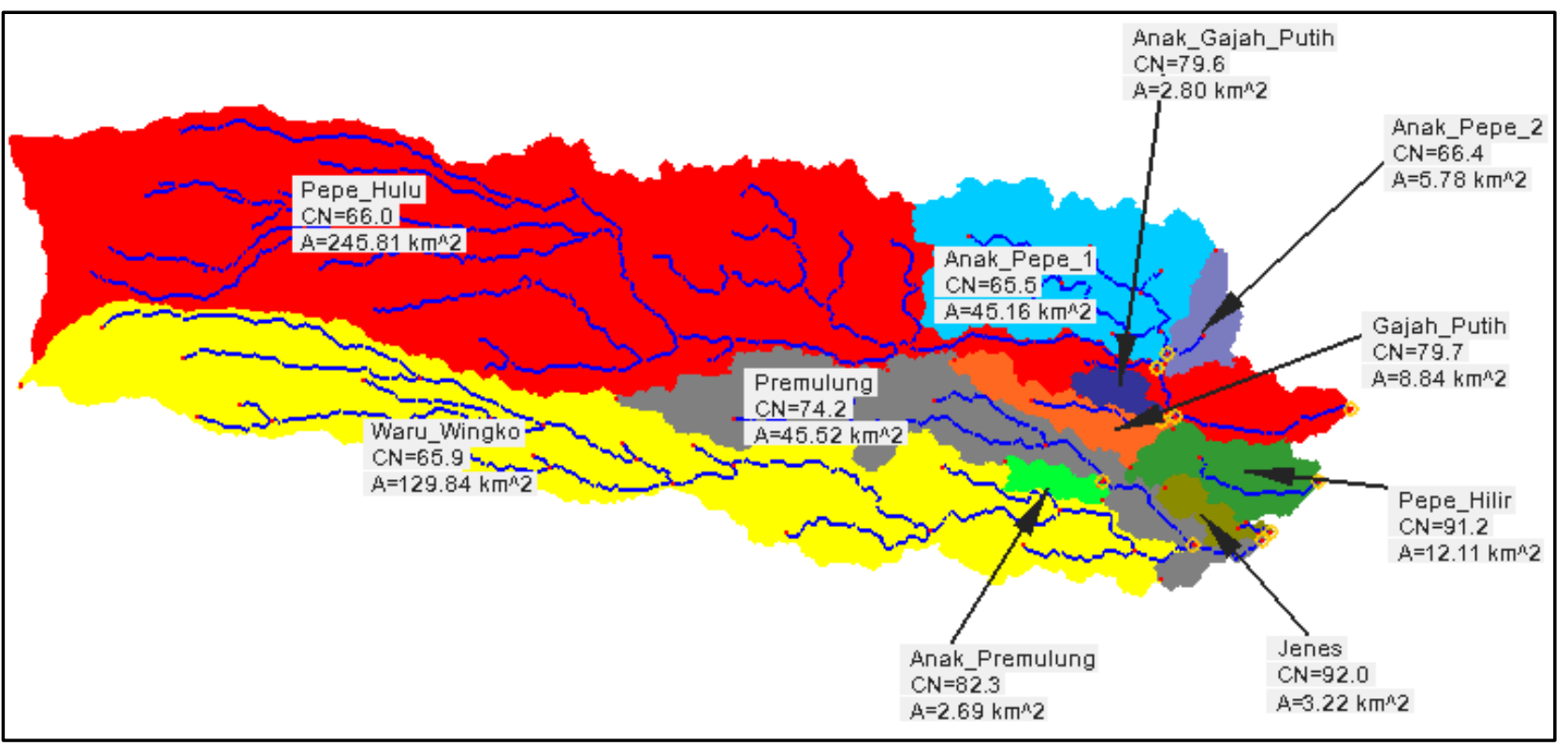

Gambar 5 Karakter DAS Wilayah Kota Surakarta (Sumber: Hasil Analisis)

Tabel 1 Nilai SCS Lag DAS 


\begin{tabular}{clcccc}
\hline \multirow{2}{*}{ NO DAS } & \multicolumn{1}{c}{ CN } & $\begin{array}{c}\text { SCS Lag } \\
\text { DAS }\end{array}$ & $\begin{array}{c}\text { Luas } \\
\left(\mathrm{km}^{2}\right)\end{array}$ & $\begin{array}{c}\text { Luas x } \\
\text { CN }\end{array}$ \\
\hline 1 & Anak Sungai Gajah Putih & 79,6 & 1,14 & 2,80 & 223,30 \\
\hline 2 & Anak Sungai Pepe 1 (S. Grembyong) & 65,5 & 4,96 & 45,16 & 2957,61 \\
\hline 3 & Anak Sungai Pepe 2 (S. Krembyongan) & 66,4 & 1,79 & 5,78 & 384,02 \\
\hline 4 & Anak Sungai Premulung (S. Brojo) & 82,3 & 1,07 & 2,69 & 221,52 \\
\hline 5 & Gajah Puth & 79,7 & 2,25 & 8,84 & 704,28 \\
\hline 6 & Jenes & 92,0 & 1,02 & 3,22 & 296,05 \\
\hline 7 & Pepe Hilir & 91,2 & 1,68 & 12,11 & 1104,96 \\
\hline 8 & Pepe Hulu & 66,0 & 9,62 & 245,81 & 16217,26 \\
\hline 9 & Premulung & 74,2 & 6,39 & 45,52 & 3378,93 \\
\hline 10 & Waru \& Wingko & 65,9 & 8,53 & 129,84 & 8560,19 \\
\hline & & & & 501,77 & 34048,12 \\
\hline
\end{tabular}

(Sumber: Hasil Analisis)

Nilai CN komposit untuk seluruh DAS yang melewati Kota Surakarta adalah 67,856

Perhitungan hujan efektif dilakukan menggunakan banutan perangkat lunak HEC-HMS dengan parameter yang telah dipilih pada WMS. Parameter yang dipilih adalah sebagai berikut:

1. Hydrologic module: HEC-HMS

2. Parameter: SCS

3. Job control: Waktu simulasi $=20$ mei 2017 00:00 sampai dengan 22 Mei 2017 24:00 ; Satuan = SI (Metric) Data kemudian disimpan sebagai file HEC-HMS agar dapat dijalankan pada HEC-HMS sebagai model DAS.

\section{Pengolahan Data Hujan}

Data hujan yang digunakan dalam perhitungan hujan wilayah adalah data hujan stasiun Mojolaban, Nepen, Ngemplak, dan Pabelan. Data hujan harian stasiun Baki, Kalijambe, dan Sukaharjo digunakan untuk pengisian data hujan yang rusak.

Pengisian data hujan yang rusak dilakukan pada stasiun hujan Ngemplak dan Mojolaban. Pengisian data hujan diisi menggunakan reciprocal method. Reciprocal method menggunakan jarak antar stasiun hujan sebagai parameternya. Jarak antar stasiun hujan dihitung menggunakan hasil plotting koordinat stasiun hujan menggunakan ArcMap.

Kepanggahan data hujan dilakukan menggunakan kurva massa ganda. Berdasarkan kurva massa ganda ditentukan bahwa data curah hujan seluruh stasiun panggah sehingga tidak perlu dilakukan perbaikan.

Perhitungan hujan wilayah menggunakan Metode Poligon Thiessen. DAS dikelompokkan berdasarkan hujan wilayahnya. DAS Bagian Utara teridiri dari DAS Pepe Hulu, Grenjeng, Krembyongan, Gajah Putih, dan Anak Gajah Putih. Bagian Tengah terdiri DAS Pepe Hilir, dan Jenes. Bagian Selatan terdiri dari DAS Wingko, Premulung-Tanggul, dan Brojo. Data hujan yang digunakan sebagai perhitungan wilayah adalah data curah hujan maksimum tahunan. Pembagian hujan wilayah dapat dilihat pada Gambar 6.

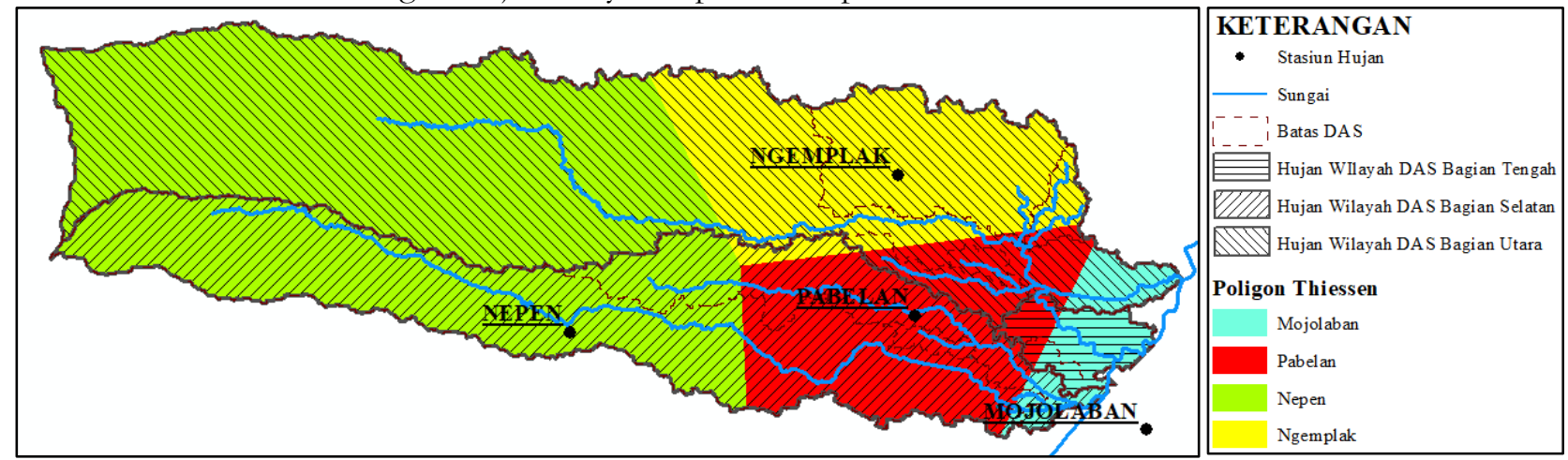

Gambar 6. Pembagian Hujan Wilayah (Sumber: Hasil Analisis)

Perhitungan hujan periode ulang 5, 10, 25, dan 50 tahun menggunakan distribusi Log Pearson III. Sebelum dilakukan perhitungan hujan periode ulang, dilakukan uji kecocokan distribusi menggunakan metode Chi Kuadrat. 
Hasil dari uji Chi Kuadrat menunjukkan setiap data curah hujan wilayah memiliki nilai $\mathrm{X}^{2}<\mathrm{X}^{2}$.r. Sehingga setiap hujan wilayah dinyatakan cocok distribusinya menggunakan Log Pearson III. Dari hasil perhitungan hujan periode ulang menggunakan distribusi Log Pearson III didapatkan nilai seperti pada Tabel 2.

Tabel 2 Hasil Perhitungan Curah Hujan Periode Ulang

\begin{tabular}{lcccc}
\hline \multirow{2}{*}{ DAS } & \multicolumn{4}{c}{ Curah Hujan Periode Ulang $(\mathrm{mm})$} \\
\cline { 2 - 5 } & 5 Tahun & 10 Tahun & 25 Tahun & 50 Tahun \\
\hline Bagian Utara & 85,139 & 92,696 & 100,568 & 105,495 \\
\hline Bagian Tengah & 84,817 & 94,568 & 106,212 & 114,494 \\
\hline Bagian Selatan & 89,769 & 98,447 & 107,722 & 113,685 \\
\hline (Sumber: Hasil Analisis) & & & &
\end{tabular}

Intensitas hujan jam jam an untuk setiap $1 \mathrm{~mm}$ kedalaman hujan dihitung menggunakan metode Mononobe, sehingga didapatkan persentase kedalaman hujan setiap jam dalam 1 hari. Persentase hujan jam jam an kemudian disusun menggunakan Alternate Block. Method sehingga didapatkan hyetograph. Hyetograf distribusi hujan dapat dilihat pada Gambar 7.

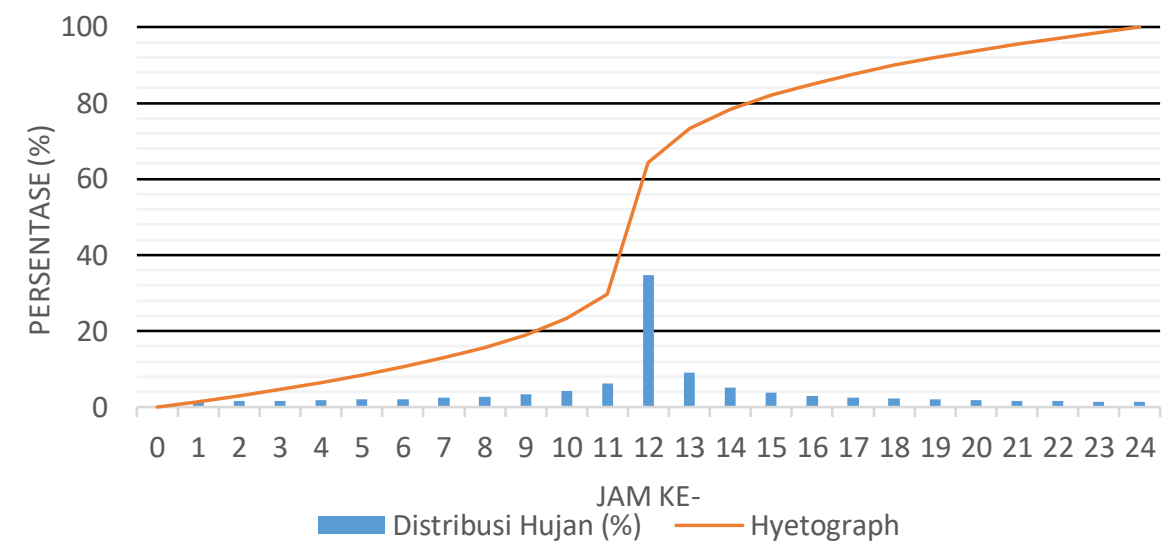

Gambar 7 Hyetograf Hujan Jam-jaman (Sumber: Hasil Analisis)

\section{Perhitungan Debit Aliran Menggunakan HEC-HMS}

Perhitungan pengalihragaman hujan menjadi debit aliran menggunakan bantuan perangkat lunak HEC-HMS. Input yang digunakan adalah model DAS hasil pengolahan data menggunakan WMS, curah hujan periode ulang dan hyetograf. Hasil perhitungan berupa hujan efektif dan hidrograf debit aliran. Debit puncak $\mathrm{Q}_{5}, \mathrm{Q}_{10}, \mathrm{Q}_{25}$, dan $\mathrm{Q}_{50}$ untuk setiap DAS dapat dilihat pada Tabel 3.

Tabel 3 Rekapitulasi Debit Puncak Periode Ulang

\begin{tabular}{ccccc}
\hline \multirow{2}{*}{ DAS } & \multicolumn{3}{c}{ Debit Puncak Periode Ulang $(\mathrm{m} 3 / \mathrm{s})$} \\
\cline { 2 - 5 } & 5 Tahun & 10 Tahun & 25 Tahun & 50 Tahun \\
\hline Anak Sungai Gajah Putih & 6,9263 & 8,0816 & 9,3361 & 10,1346 \\
\hline Anak Sungai Pepe 1 (Grenjeng) & 19,3659 & 24,1769 & 29,5741 & 33,1335 \\
\hline Anak Sungai Pepe 2 (Krombyongan) & 4,6949 & 5,9324 & 7,3142 & 8,2345 \\
\hline Anak Sungai Premulung & 8,6536 & 10,0666 & 11,6042 & 12,6038 \\
\hline Gajah Putih & 14,9796 & 17,4630 & 20,1106 & 21,7955 \\
\hline Jenes & 14,3935 & 16,4549 & 18,9128 & 20,6571 \\
\hline Pepe Hilir & 40,3742 & 46,3434 & 53,5443 & 58,6725 \\
\hline Pepe Hulu & 74,4676 & 91,4747 & 110,3932 & 122,8158 \\
\hline Premulung & 32,6550 & 39,1877 & 46,4538 & 51,2903 \\
\hline Waru \& Wingko & 47,9801 & 59,7032 & 73,1283 & 82,1925 \\
\hline (Sumber: Hasil Analisis) & & & &
\end{tabular}

\section{Penelusuran Banjir Menggunakan HEC-RAS}

Penelusuran Banjir dilakukan untuk menentukan kedalman dan luasan banjir. Perhitungan penelusuran banjir dilakukan dengan simulasi aliran tidak tetap menggunakan HEC-RAS. Input yang dibutuhkan adalah geometri 
sungai dan hidrograf debit aliran. Geometri sungai dibuat dengan digitasi menggunakan RasMapper. Data terrain yang digunakan pada RasMapper adalah peta DEM gabungan yang telah di olah sebelumnya. Data geometri pada sungai yang tidak terdapat pada peta DEM digunakan data survey dan dilakukan interpolasi antar cross section. Karena geometri pada daerah pertemuan sungai diabaikan, maka aliran yang masuk dari anak sungai dijadikan input aliran lateral.

Hasil dari HEC-RAS adalah peta raster yang berisi informasi kedalaman banjir dan luasasn banjir. Peta tersebut dibaca menggunakan RasMapper. Peta kedalaman banjir dan luasan banjir diekspor menjadi format .shp agar bisa diolah menggunakan ArcMap.

\section{Pemetaan Banjir}

Peta Luasan Banjir diolah menggunakan ArcMap. Potensi luasan banjir untuk setiap kelurahan dapat dilihat pada tabel 4. Potensi kedalaman maksimum banjir dan lokasinya dapat dilihat pada tabel 5 .

Tabel 4 Potensi Luasan Banjir Periode Ulang Setiap Kelurahan

\begin{tabular}{ccccc}
\hline \multirow{2}{*}{ Kelurahan } & \multicolumn{4}{c}{ Luasan Banjir Periode Ulang } \\
\cline { 2 - 5 } & 5 Tahun $\left(\mathrm{m}^{2}\right)$ & 10 Tahun $\left(\mathrm{m}^{2}\right)$ & 25 Tahun $\left(\mathrm{m}^{2}\right)$ & 50 Tahun $\left(\mathrm{m}^{2}\right)$ \\
\hline Banyunyar & 108427,8125 & 130067,388 & 211375,5988 & 223630,0333 \\
\hline Gilingan & 56731,0699 & 89500,7394 & 75386,82602 & 90484,70534 \\
\hline Jajar & - & - & 1024,433412 & 183,2739726 \\
\hline Joyotakan & - & - & 4746,706492 & 9037,696002 \\
\hline Kadipiro & 19339,68092 & 18837,736 & 44122,04091 & 46154,57128 \\
\hline Karangasem & 244,114 & - & 2370,405687 & 2757,378919 \\
\hline Kerten & 43545,02924 & 49482,6584 & 45651,11528 & 45356,11587 \\
\hline Kestalan & 70233,47523 & 89375,6642 & 105216,5417 & 115157,8854 \\
\hline Ketelan & 44626,51111 & 52204,0886 & 60194,58211 & 643338,42628 \\
\hline Manahan & 7272,728574 & 20469,4679 & 31108,82483 & 16028,09421 \\
\hline Mangkubumen & 47776,57408 & 52090,4571 & 64571,36855 & 92383,42935 \\
\hline Nusukan & 982,3315794 & 29379,7071 & 8004,442562 & 0,10304329 \\
\hline Pajang & 34534,74406 & 1,35599115 & 75777,89125 & 63738,02817 \\
\hline Punggawan & 13403,5469 & 15961,1008 & 24503,55442 & 32654,37424 \\
\hline Serengan & 25 & 158590,528 & 158590,5279 & 158590,5279 \\
\hline Setabelan & - & - & - & 11,34734832 \\
\hline Sondakan & 2411,703368 & - & - & - \\
\hline Sumber & 92728,60766 & 119393,186 & 120220,8537 & 131310,662 \\
\hline Total Luasan & 539871,2258 & 825354,0782 & 1032881,629 & 1091835,089 \\
\hline
\end{tabular}

(Sumber: Hasil Analisis)

Tabel 5 Potensi Kedalaman Banjir Periode Ulang

\begin{tabular}{ccl}
\hline Banjir Periode ulang & Kedalaman $(\mathrm{m})$ & Lokasi \\
\hline 5 Tahunan & 5,10 & Banyuanyar \\
\hline 10 Tahunan & 5,58 & Banyuanyar \\
\hline 25 Tahunan & 8,02 & Banyuanyar \\
\hline 50 Tahun & 8,23 & Banyuanyar \\
\hline
\end{tabular}

(Sumber: Hasil Analisis)

Berdasarkan Tabel 4 dan Tabel 5 daerah yang berpotensi mengalami banjir paling parah adalah Kelurahan Banyuanyar. Peta potensi banjir setiap periode ulang dapat dilhat pada Gambar 7 sampai dengan Gambar 10. 


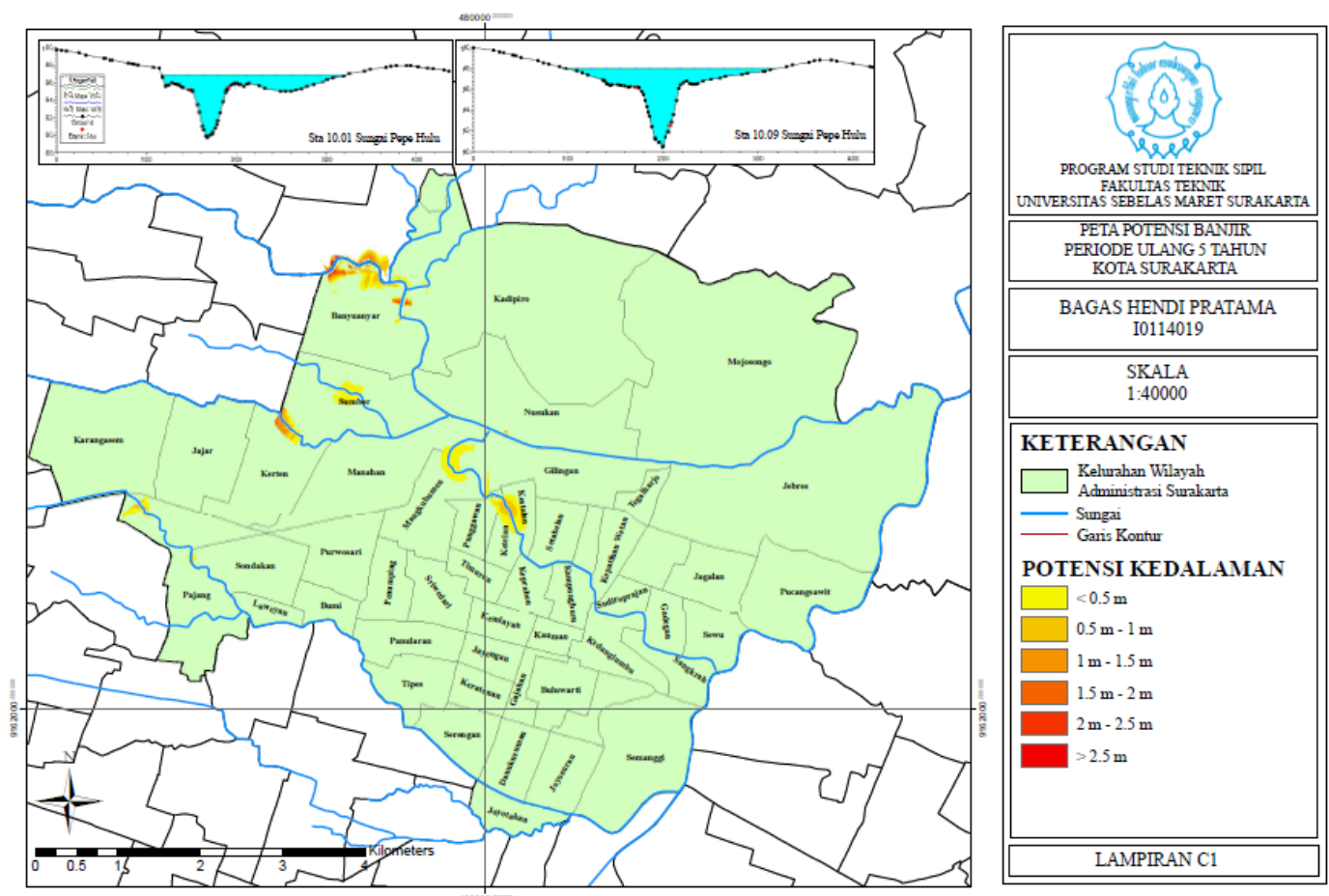

Gambar 7 Peta Potensi Banjir Periode Ulang 5 Tahun (Sumber: Hasil Analisis)

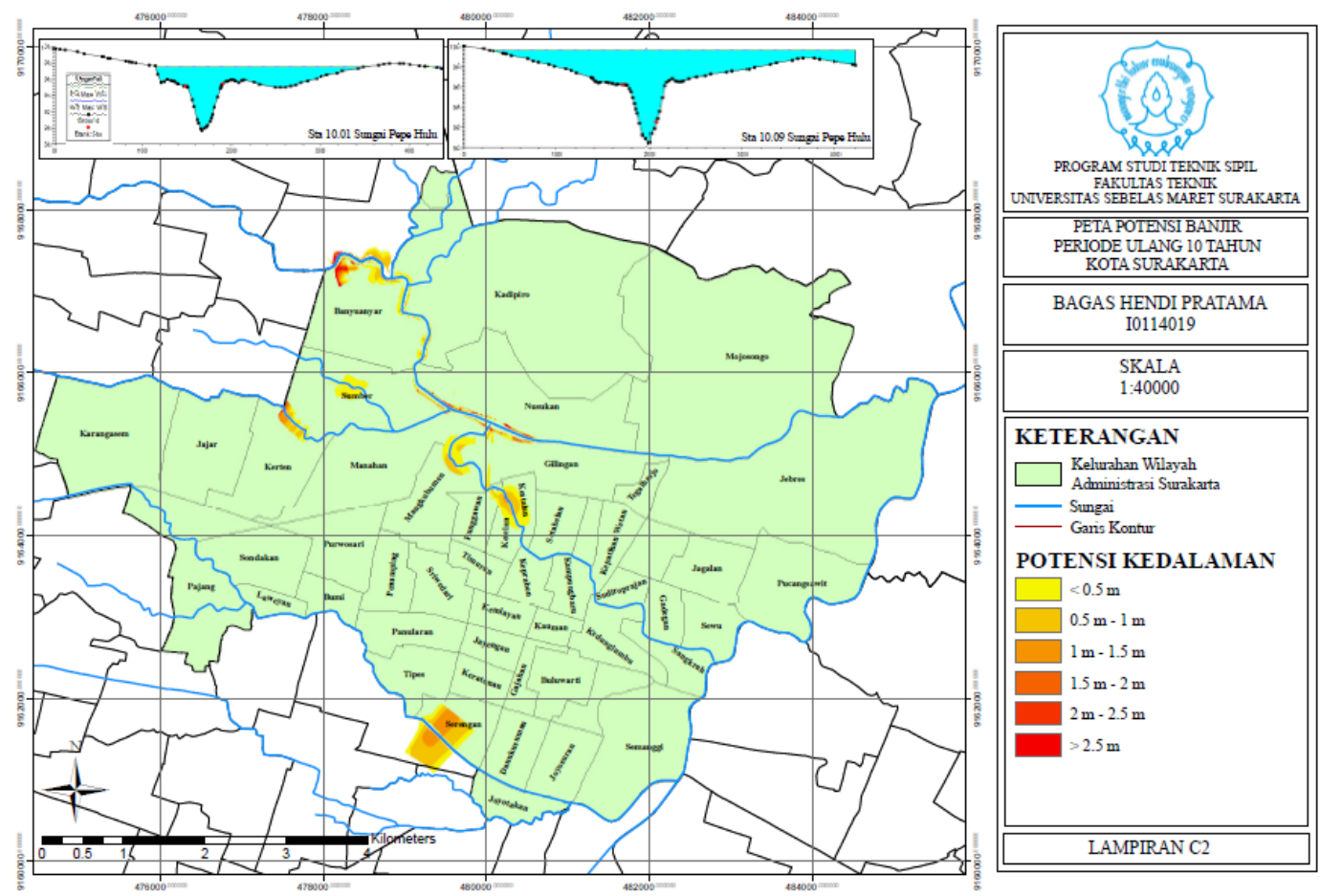

Gambar 8 Peta Potensi Banjir Periode Ulang 10 Tahun (Sumber: Hasil Analisis) 


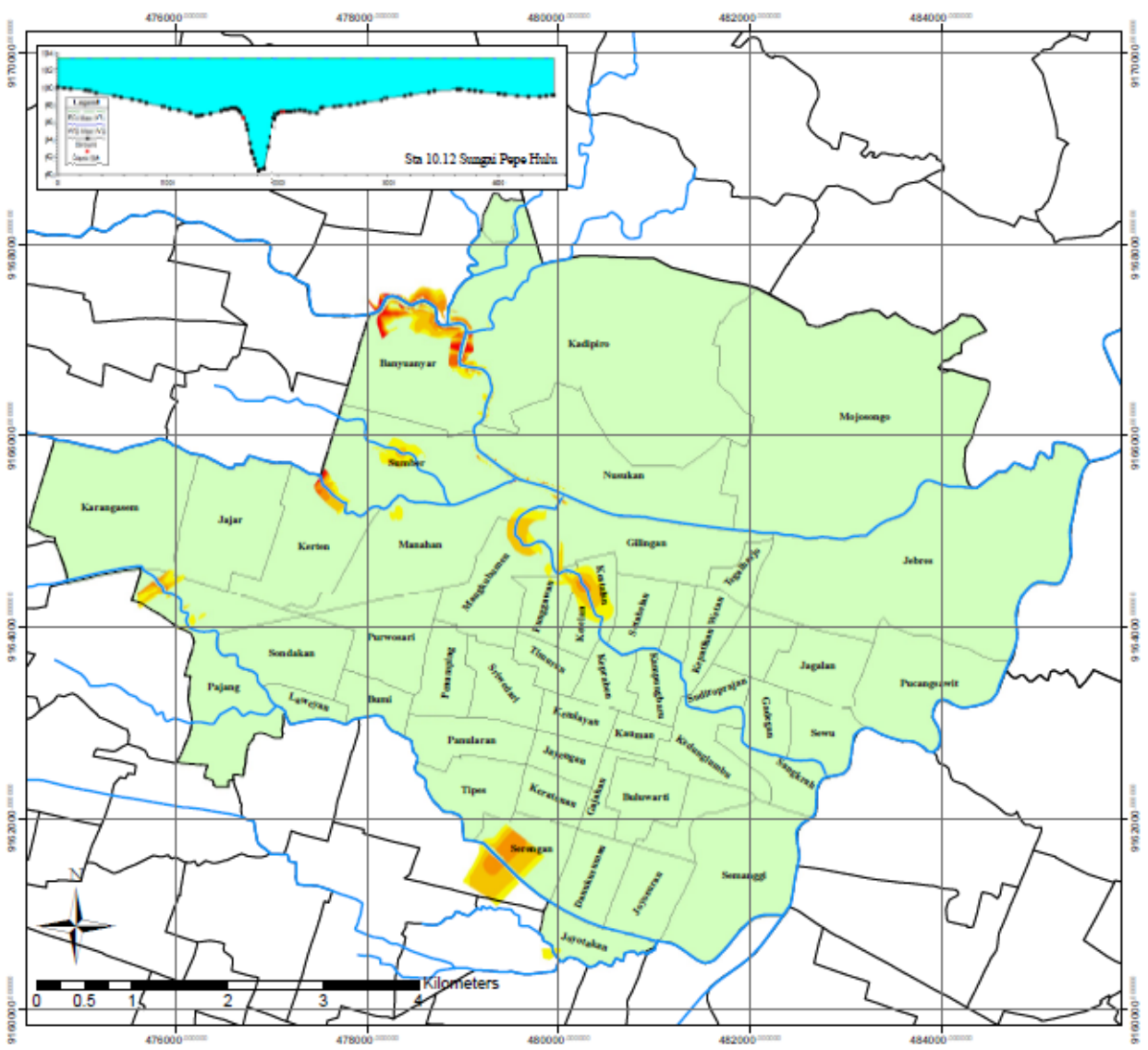

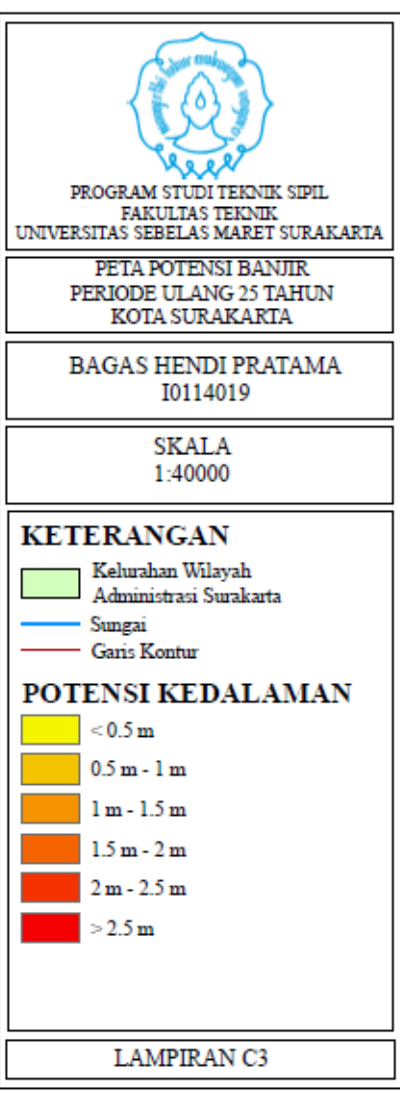

Gambar 9 Peta Potensi Banjir Periode Ulang 25 Tahun (Sumber: Hasil Analisis)
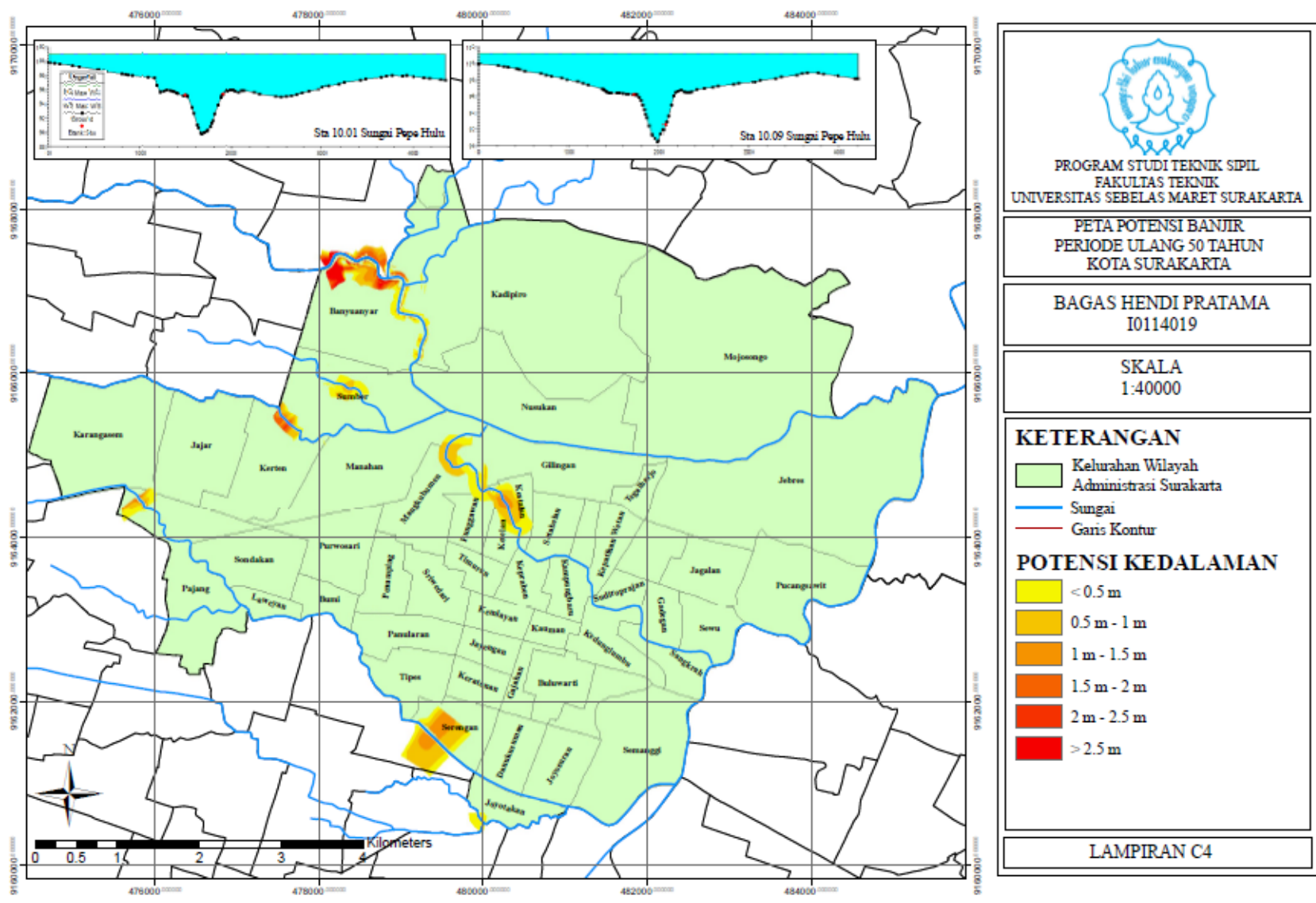

Gambar 10 Peta Potensi Banjir Periode Ulang 50 Tahun (Sumber: Hasil Analisis) 


\section{SIMPULAN}

Kesimpulan dari penelitian ini adalah

1. Nilai Curve Number untuk DAS yang melewati Kota Surakarta adalah 67,856

2. Debit puncak pada DAS yang paling besar, yaitu DAS Pepe Hulu, adalah $\mathrm{Q}_{5}=74,468 \mathrm{~m}^{3} / \mathrm{s}, \mathrm{Q}_{10}=91,475$ $\mathrm{m}^{3} / \mathrm{s}, \mathrm{Q}_{25}=110,393 \mathrm{~m}^{3} / \mathrm{s}, \mathrm{Q}_{50}=122,816 \mathrm{~m}^{3} / \mathrm{s}$. Dan debit puncak pada DAS yang paling kecil yaitu DAS Brojo adalah $\mathrm{Q}_{5}=8,654 \mathrm{~m}^{3} / \mathrm{s}, \mathrm{Q}_{10}=10,067 \mathrm{~m}^{3} / \mathrm{s}, \mathrm{Q}_{25}=11,604 \mathrm{~m}^{3} / \mathrm{s}, \mathrm{Q}_{50}=12,603 \mathrm{~m}^{3} / \mathrm{s}$

3. Potensi kedalaman maksimum adalah: Kedalaman banjir $\mathrm{Q}_{5}=5,09 \mathrm{~m}$, kedalaman banjir $\mathrm{Q}_{10}=5,57 \mathrm{~m}$, kedalaman banjir $\mathrm{Q}_{25}=8,02 \mathrm{~m}$, kedalaman banjir $\mathrm{Q}_{50}=8,23 \mathrm{~m}$. Kedalaman banjir maksimum untuk seluruh periode ulang terjadi di Kelurahan Banyanyar.

4. Potensi total luasan banjir setiap periode ulang adalah: Luasan banjir Q5 $=53,987 \times 10^{4} \mathrm{~m}^{2}$, luasan banjir Q10 $=82,535 \times 10^{4} \mathrm{~m}^{2}$, luasan banjir Q25 $=103,288 \times 10^{4} \mathrm{~m}^{2}$, luasan banjir Q50 $=109,184 \times 10^{4} \mathrm{~m}^{2}$. Kelurahan dengan potensil luasan paling besar adalah Kelurahan Banyuanyar.

\section{REKOMENDASI}

1. Disarankan dilakukan penelitian lebih lanjut dengan memperhitungkan geometri pertemuan sungai.

2. Disarankan dilakukan penelitian lebih lanjut tentang pengaruh adanya bangunan air terhadap banjir yang terjadi.

3. Warga Surakarta lebih sadar tentang bahaya banjir dan penanggulangannya.

\section{REFERENSI}

Akhmad Adi, S. dan Tunggul Sutan, H. 2006. Definisi Numerik Jaringan Drainase dan Daerah Aliran Sungai dari Model Elevasi Digital untuk Model Hidrologi. Fakultas Teknlogi Pertanian Universitas Brawijaya. Malang.

Asdak, C. 1995. Hidrologi dan Pengelolaan Daerah Aliran Sungai. Gadjah Mada University Press. Yogyakarta. Ayu Prawesti, N. 2012. Analisis Banjir Tahunan Daerah Aliran Sungai Bengawan Solo Hulu Sub DAS Bengawan Solo Hulu 3. Universitas Sebelas Maret. Surakarta.

Bambang, T.. 2006. Hidrologi Terapan II. Beta Offset. Yogyakarta.

Kementrian Pekerjaan Umum dan Perumahan Rakyat Republik Indonesia. Peraturan Menteri Pekerjaan Umum dan Perumahan Rakyat Republik Indonesia Nomor 25/PRT/M/2014 Tentang Penyelenggaraan Data dan Informasi Geospasial Infrastruktur Bidang Pekerjaan Umum dan Perumahan Rakyat. 2014.

Restu, W. 2016. Analisis Banjir Menggunakan Software HEC-RAS 4.1.0 (Studi Kasus Sub-DAS Ciberang HM 0+00 - HM 34+00). Universitas Sultan Ageng Tirtayasa. Cilegon.

Rintis, H. dan Setiono. 2015. Analysis of Rainfall-runoff Neuron Input Model with Artificial Neural Network for Simulation for availability of discharge at Bah Bolon Watershed. Universitas Sebelas Maret. Surakarta.

Rifai, M. 2015. Kajian Hujan-Aliran Menggunakan Model HEC-HMS di Sub Daerah Aliran Sungai Wuryantoro, Wonogiri, Jawa Tengah. Universitas Gajah Mada. Yogyakarta.

Sharkh. Majed, S.A. 2009. Estimation of Runoff For Small Watershed Using Watershed Modelling System (WMS) and GIS. Palestine Polythecnic University. Palestina.

Suripin. 2004. Sistem Drainase Perkotaan yang Berkelanjutan. Andi Offset. Yogyakarta. 